\title{
Research on Security Evaluation of Modern Information Service Industry in China
}

\author{
Li Menggang and Chen Fenfei \\ China Center for Industrial Security Research, Beijing Jiaotong University, \\ China \\ School of Economics and Management, Beijing Jiaotong University, China \\ Beijing Center for Industrial Security and Development Research, Beijing \\ Jiaotong University, China \\ E-mail:morganli@vip.sina.com,ffchen@bjtu.edu.cn
}

\begin{abstract}
With the development of economy and society, more and more attention has been paid to security of modern information service industry. This paper set up a security evaluation index system which is made up of 23 indexes from three perspectives of domestic environment, international competitiveness and external dependence of the industry. Besides, it also conducted a preliminary evaluation on security of China's modern information service industry from 2007 to 2011 by adopting the method of principal component analysis. The composite scores are -3.66, -1.56, -1.09, 1.95 and 4.37 respectively while results of the varimax rotation show that important factors influencing security of China's modern information service industry in recent years include return on sales, capital efficiency, labor productivity, macro environment and market demand growth rate. Therefore, from now on, we should promote security and development of modern information service industry through actively enhancing the domestic industrial environment and industrial competitiveness and effectively exerting control on the industry.
\end{abstract}

Keywords: modern information service industry; industry security; principal component analysis; varimax rotation

\section{Introduction}

With the constant development of science and technology and the increasing innovation of business models, technology becomes increasingly integrated with industry, and modern information service industry represented by software and digital audio and video has also become the focus of international competition and a strategic leading industry developed by all countries. Despite of the fact that China's information service industry is still in its infancy and accounts for a small proportion in the information industry market with a growth rate far exceeding the average economic growth rate, the information service industry is still expected to develop at a high speed in the future with the proceeding of informationization in China. Meanwhile, industry security has become a common problem the world.

\section{Construction of Security Evaluation Index System for Modern Information Service Industry}

In accordance with design principles of scientificity, system optimization and practicability, in combination with the characteristics of the modern information service industry, this paper sets up a security evaluation index system for the modern information service industry from three perspectives of domestic environment, international 
competitiveness and external dependence of the industry. Among them, its domestic environment consists of industrial growth, capital environment, labor environment and industrial policy environment, which are the key driving force facilitating development of the industry. Factors like output, cost, human resource and asset are also important indicators measuring the industrial development. Therefore, the domestic environment of the industry is mainly used to evaluate development of enterprises in terms of production factors, technology and management. Indicators of global competitiveness of the industry can be analyzed from two aspects of result and reason, and this paper demonstrates the proportion and profit of China's modern information service industry in the international market with indicators of market competitiveness, brand competitiveness and performance, market structure and efficiency. External dependence of the industry refers to its external dependence in terms of export, import, capital and technology and reflects the mutual reliance of one country's economy on that of other countries or even the world. This paper selected two indicators of external dependence and industrial control to manifest the external dependence of the industry. Based on the above analysis, the paper selected a total amount of 23 indicators within the category of different secondary indexes and quantized data by adopting a simple and operable method which is shown in Table 1.

Table 1. Security Index System of Modern Information Service Industry

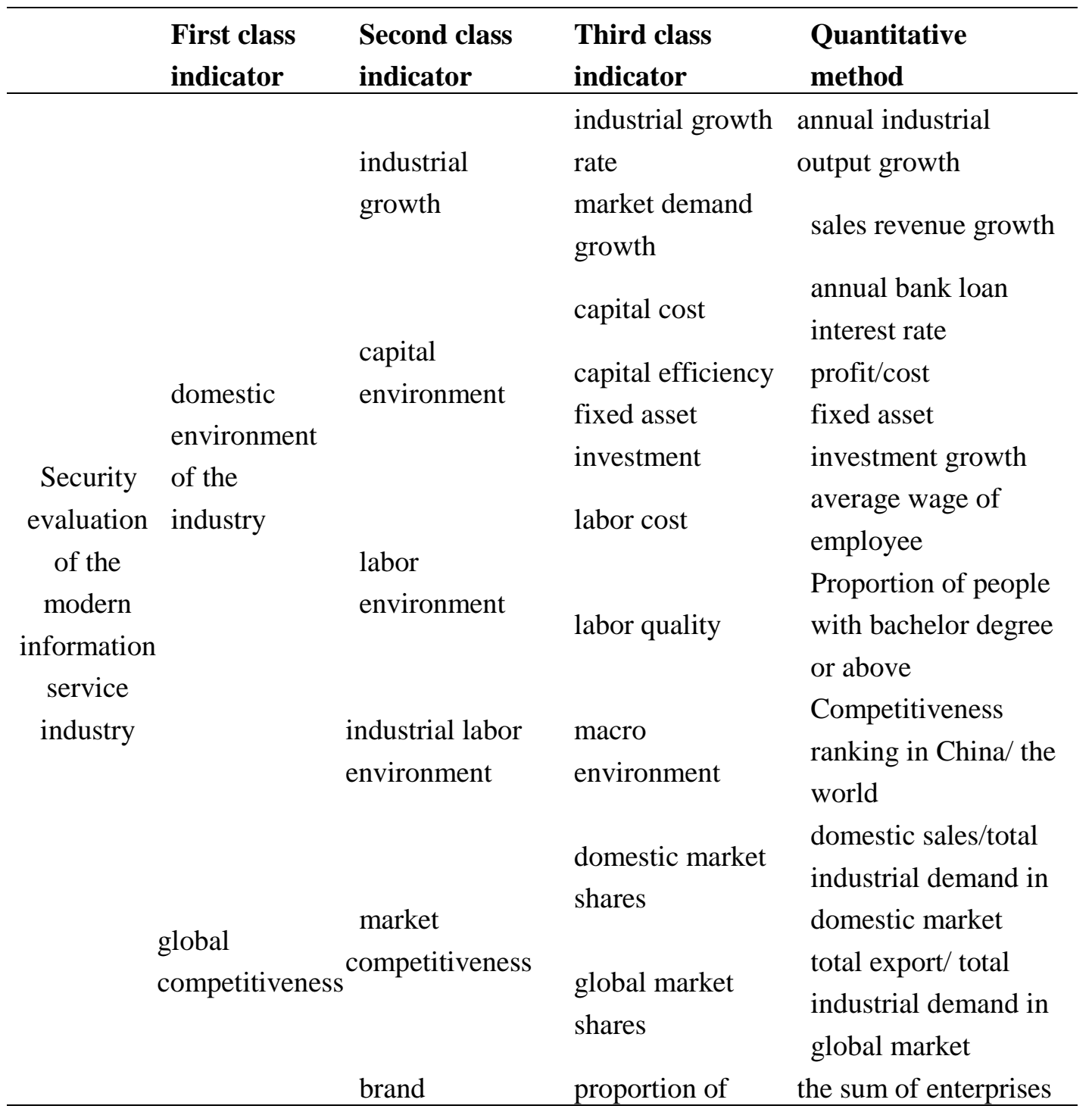




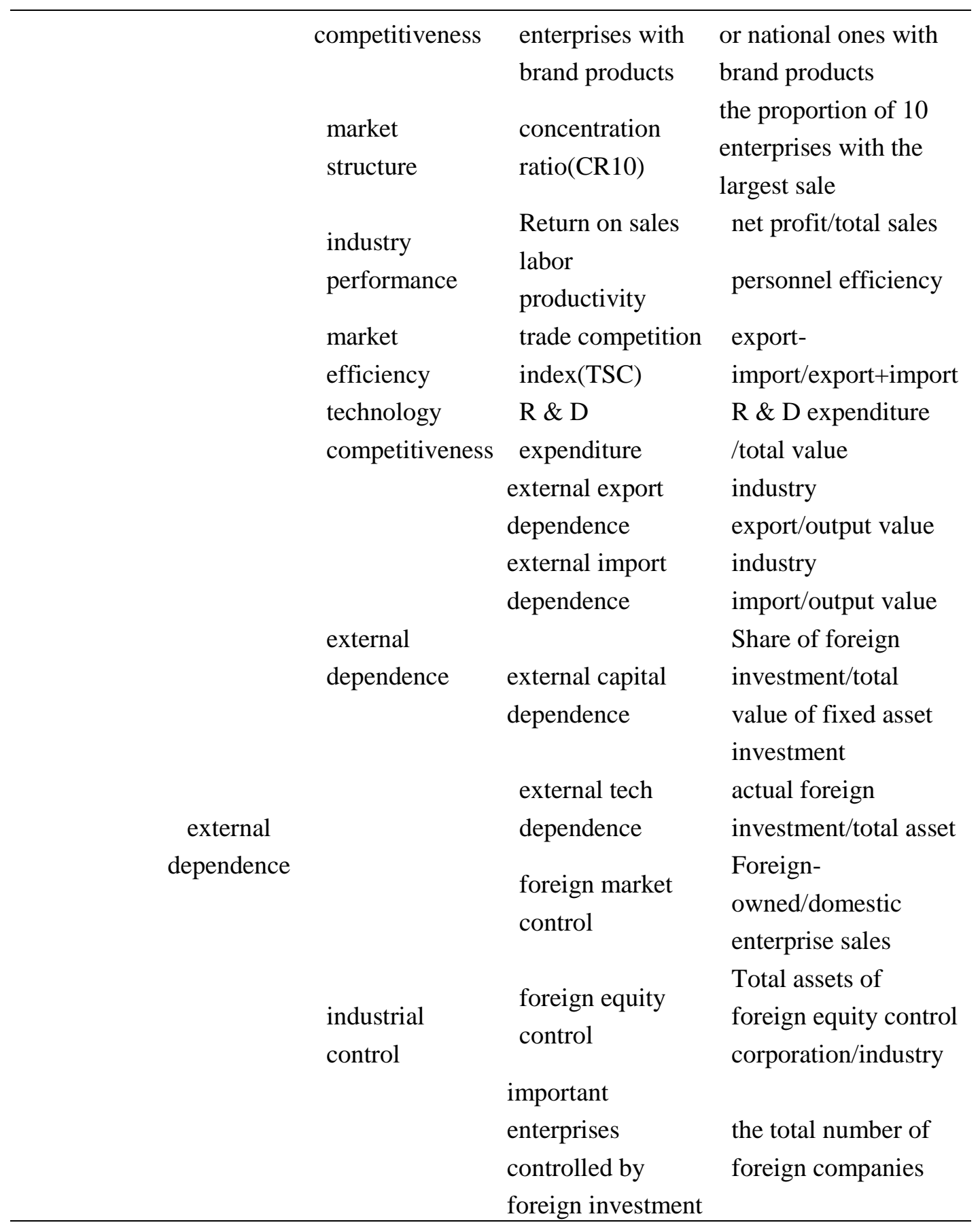

\section{Empirical Analysis on the Security of Modern Information Service Industry}

\subsection{Data Analysis}

In 2003, the State Statistics Bureau issued temporary provisions classifying information related industries statistically which defines the scope and classification of China's modern information service industry. According to those temporary provisions, the information industry falls into five categories, including electronic information equipment manufacturing, electronic information equipment sales and leasing, electronic information transmission services, computer services and software and other information related services among which the latter three are usually referred to as the modern 
information service industry and also the subject of this paper. Based on data in China Statistical Yearbook, Electronic Information Industry Statistics Yearbook and Report to the Development of China's Software and Information, this paper calculated index data of the modern information service industry ranging from 2007 to 2011 which is shown in Table 2.

Table 2. Index Data of the Modern Information Service Industry

\begin{tabular}{|c|c|c|c|c|c|}
\hline Indicators & 2007 & 2008 & 2009 & 2010 & 2011 \\
\hline annual industrial output growth (\%) & 21.54 & 29.81 & 25.62 & 40.48 & 38.71 \\
\hline sales revenue growth $(\%)$ & 21.52 & 29.80 & 31.66 & 36.29 & 38.71 \\
\hline annual bank loan interest rate $(\%)$ & 6.67 & 7.20 & 5.31 & 5.35 & 6.35 \\
\hline profit/cost $(\%)$ & 11.12 & 13.69 & 15.54 & 19.05 & 17.42 \\
\hline fixed asset investment growth (\%) & -1.48 & 17.02 & 19.72 & -5.20 & -11.41 \\
\hline average wage of employee (yuan) & 47700 & 54906 & 58154 & 64436 & 70918 \\
\hline $\begin{array}{l}\text { ratio of people with bachelor degree or } \\
\text { above }(\%)\end{array}$ & 63.23 & 66.53 & 61.85 & 63.80 & 64.82 \\
\hline $\begin{array}{l}\text { competitiveness ranking in China/ the } \\
\text { world }\end{array}$ & 34 & 30 & 29 & 27 & 26 \\
\hline $\begin{array}{l}\text { domestic sales/total industrial demand } \\
\text { in domestic market }(\%)\end{array}$ & 87.54 & 85.03 & 86.39 & 86.82 & 81.63 \\
\hline $\begin{array}{l}\text { total export/ total industrial demand in } \\
\text { global market }(\%)\end{array}$ & 8.74 & 11.07 & 14.5 & 18 & 18.36 \\
\hline $\begin{array}{l}\text { the sum of enterprises or national ones } \\
\text { with brand products }(\%)\end{array}$ & 85.84 & 85.74 & 86.59 & 87.52 & 88.66 \\
\hline $\begin{array}{l}\text { the proportion of } 10 \text { enterprises with } \\
\text { the largest sale }(\%)\end{array}$ & 16.56 & 16.72 & 15.16 & 14.07 & 10.54 \\
\hline net profit/total sales $(\%)$ & 10 & 12 & 13.4 & 16 & 14.8 \\
\hline $\begin{array}{l}\text { personnel efficiency（million/per } \\
\text { capita） }\end{array}$ & 14.75 & 17.58 & 18.5 & 20.8 & 20.9 \\
\hline (export-import) / (export+import) & 0.25 & 0.25 & 0.27 & 0.44 & 0.47 \\
\hline $\mathrm{R} \& \mathrm{D}$ expenditure /total value $(\%)$ & 8.94 & 10.86 & 7.33 & 8.32 & 8.94 \\
\hline industry export/output value (\%) & 12.46 & 14.97 & 13.61 & 13.18 & 18.37 \\
\hline industry import/output value (\%) & 4.30 & 4.31 & 3.16 & 2.08 & 1.71 \\
\hline $\begin{array}{l}\text { Share of foreign investment/total value } \\
\text { of fixed asset investment }(\%)\end{array}$ & 22.60 & 22.24 & 23.52 & 26.11 & 25.94 \\
\hline $\begin{array}{l}\text { actual foreign investment/total asset（ } \\
\%)\end{array}$ & 1.94 & 2.54 & 1.61 & 1.26 & 0.92 \\
\hline $\begin{array}{l}\text { Foreign-owned/domestic enterprise } \\
\text { sales }(\%)\end{array}$ & 32.83 & 34.37 & 32.27 & 31.62 & 28.90 \\
\hline $\begin{array}{l}\text { Total assets of foreign equity control } \\
\text { corporation/industry }(\%)\end{array}$ & 28.45 & 20.97 & 27.20 & 26.21 & 20.36 \\
\hline $\begin{array}{l}\text { the total number of foreign companies } \\
(\%)\end{array}$ & 14.16 & 14.26 & 13.41 & 12.48 & 11.34 \\
\hline
\end{tabular}




\subsection{Calculation of Industrial Security}

This paper adopts the method of principal component analysis to measure the security of China's modern information service industry, the merit of which lies in its weight that is mainly about the internal structural relationship among indicators obtained through data analysis without being influenced by subjective factors. Besides, principal components involved are independent from each other and have less overlapping of information, thus ensuring the objectivity and certainty of evaluation results. With the help of the SPSS 19.0 software, principal component analysis is conducted on the basis of standardized data of 23 indicators reflecting security of modern information service industry ranging from 2007 to 2011 which are shown in Table 2. Results of eigen-value, component matrix and variance contribution rate are demonstrated in Table 3 and Table 4.

Table 3. Total Variance of Explanation

\begin{tabular}{|c|c|c|c|c|c|c|}
\hline \multirow[b]{2}{*}{ component } & \multicolumn{3}{|c|}{ Initial eigen-value } & \multicolumn{3}{|c|}{ Extraction of squares and loading } \\
\hline & $\begin{array}{l}\text { Eigen- } \\
\text { value }\end{array}$ & variance $\%$ & $\begin{array}{c}\text { accumulation } \\
\% \\
\end{array}$ & $\begin{array}{c}\text { Eigen- } \\
\text { value }\end{array}$ & $\begin{array}{c}\text { variance } \\
\% \\
\end{array}$ & $\begin{array}{c}\text { accumulation } \\
\% \\
\end{array}$ \\
\hline 1 & 15.790 & 68.651 & 68.651 & 15.790 & 68.651 & 68.651 \\
\hline 2 & 4.364 & 18.974 & 87.625 & 4.364 & 18.974 & 87.625 \\
\hline 3 & 1.804 & 7.844 & 95.469 & 1.804 & 7.844 & 95.469 \\
\hline 4 & 1.042 & 4.531 & 100.000 & 1.042 & 4.531 & 100.000 \\
\hline
\end{tabular}

As we can see from the output, the accumulating contribution rate of former two principal components reach $87.625 \%$, so these two components are selected to be principal ones in accordance with the principle that the accumulating variance contribution rate should be over $85 \%$. As a result, two principal components of F1 and F2 are selected conforming to the extraction principle of principal components, which has not only retained the original information of indicators but also succeeded to reduce dimensions.

Table 4. Component Matrix

\begin{tabular}{lcrrr}
\hline & \multicolumn{4}{c}{ Component } \\
& $\mathbf{1}$ & $\mathbf{2}$ & $\mathbf{3}$ & \multicolumn{1}{c}{$\mathbf{4}$} \\
\hline $\mathrm{X}_{1}:$ annual industrial output growth $(\%)$ & .891 & .183 & .246 & .335 \\
$\mathrm{X}_{2}$ : sales revenue growth (\%) & .943 & .109 & .297 & -.102 \\
$\mathrm{X}_{3}:$ annual bank loan interest rate $(\%)$ & -.460 & .842 & -.258 & .108 \\
$\mathrm{X}_{4}$ : profit/cost (\%) & .906 & -.167 & .376 & .097 \\
$\mathrm{X}_{5}$ : fixed asset investment growth (\%) & -.590 & -.019 & .606 & -.533 \\
$\mathrm{X}_{6}:$ average wage of employee & .985 & .116 & .086 & -.092 \\
$\mathrm{X}_{7}:$ ratio of people with bachelor degree or above & .042 & .939 & .193 & .283 \\
$\mathrm{X}_{8}:$ competitiveness ranking in China/ the world & -.933 & -.094 & -.325 & .119 \\
$\mathrm{X}_{9}:$ domestic sales/total industrial demand in & -.652 & -.643 & .209 & .343 \\
domestic market & & & & \\
$\mathrm{X}_{10}$ : total export/ total industrial demand in global & .974 & -.135 & .182 & -.024 \\
market & & & & \\
\hline
\end{tabular}




\begin{tabular}{lrrrr}
\hline $\mathrm{X}_{11}$ : the sum of enterprises or national ones with & .977 & -.007 & -.212 & -.028 \\
brand products & & & & \\
$\mathrm{X}_{12}$ : the proportion of 10 enterprises with the & -.937 & -.098 & .306 & .139 \\
largest sale & & & & \\
$\mathrm{X}_{13}$ : net profit/total sales (\%) & .906 & -.162 & .381 & .088 \\
$\mathrm{X}_{14}:$ personnel efficiency (million/per capita) & .945 & .018 & .327 & -.017 \\
$\mathrm{X}_{15}: \quad$ (export-import) / (export+import) & .957 & .010 & -.112 & .268 \\
$\mathrm{X}_{16}: \mathrm{R}$ \& D expenditure /total value & -.306 & .903 & .103 & .285 \\
$\mathrm{X}_{17}:$ industry export/output value (\%) & .652 & .643 & -.209 & -.343 \\
$\mathrm{X}_{18}:$ industry import/output value (\%) & -.983 & .178 & .033 & -.022 \\
$\mathrm{X}_{19}:$ Share of foreign investment/total value of & .950 & -.203 & -.043 & .234 \\
fixed asset investment & & & & \\
$\mathrm{X}_{20}$ : actual foreign investment/total asset & -.877 & .353 & .326 & .018 \\
$\mathrm{X}_{21}$ : Foreign-owned/domestic enterprise sales & -.868 & .079 & .475 & .120 \\
$\mathrm{X}_{22}:$ Total assets of foreign equity control & -.428 & -.882 & -.123 & .155 \\
corporation/industry (\%) & & & & \\
$\mathrm{X}_{23}$ : the total number of foreign companies & -.977 & .007 & .212 & .028 \\
\hline
\end{tabular}

There is a relationship formula between the component matrix and the principal component coefficient vector matrix which is as follows:

$$
A^{\prime}=A \times \operatorname{diag}\left(\sqrt{\lambda_{1}}, \sqrt{\lambda_{2}}, \ldots, \sqrt{\lambda_{p}}\right)=\left(a^{(1)} \sqrt{\lambda_{1}}, a^{(2)} \sqrt{\lambda_{2}}, \ldots, \quad a^{(p)} \sqrt{\lambda_{p}}\right)
$$

In this formula, $\mathrm{A}^{\prime}$ refers to the factor loading matrix while $\lambda_{j}(j=1,2, \ldots \ldots, p)$ is eigen-value of each common factor, that is, eigen-value of the original observation variable covariance matrix. As a result, we can put forward the following formulas of principal component coefficient vectors:

$$
\begin{aligned}
\mathrm{F} 1 & =0.224 \mathrm{X}_{1}+0.237 \mathrm{X}_{2}+0.116 \mathrm{X}_{3}+0.228 \mathrm{X}_{4}-0.148 \mathrm{X}_{5}+0.248 \mathrm{X}_{6} \\
& +0.106 \mathrm{X}_{7}-0.235 \mathrm{X}_{8}-0.164 \mathrm{X}_{9}+0.245 \mathrm{X}_{10}+0.246 \mathrm{X}_{11}-0.236 \mathrm{X}_{12} \\
& +0.228 \mathrm{X}_{13}+0.238 \mathrm{X}_{14}+0.241 \mathrm{X}_{15}-0.077 \mathrm{X}_{16}+0.164 \mathrm{X}_{17}-0.247 \mathrm{X}_{18} \\
& +0.239 \mathrm{X}_{19}-0.221 \mathrm{X}_{20}-0.218 \mathrm{X}_{21}-0.108 \mathrm{X}_{22}-0.246 \mathrm{X}_{23} \\
\mathrm{~F} 2 & =0.088 \mathrm{X}_{1}+0.052 \mathrm{X}_{2}+0.403 \mathrm{X}_{3}-0.080 \mathrm{X}_{4}-0.009 \mathrm{X}_{5}+0.056 \mathrm{X}_{6} \\
& +0.449 \mathrm{X}_{7}-0.045 \mathrm{X}_{8}-0.308 \mathrm{X}_{9}-0.065 \mathrm{X}_{10}-0.003 \mathrm{X}_{11}-0.047 \mathrm{X}_{12} \\
& -0.078 \mathrm{X}_{13}+0.009 \mathrm{X}_{14}+0.005 \mathrm{X}_{15}+0.432 \mathrm{X}_{16}+0.308 \mathrm{X}_{17}+0.085 \mathrm{X}_{18} \\
& -0.097 \mathrm{X}_{19}+0.169 \mathrm{X}_{20}+0.038 \mathrm{X}_{21}-0.422 \mathrm{X}_{22}+0.003 \mathrm{X}_{23}
\end{aligned}
$$

The following formula of synthesis score is obtained through calculating the weight value of each principal component with the help of eigen-value.

$$
Y=\frac{\lambda_{1} F 1+\lambda_{2} F 2}{\lambda_{1}+\lambda_{2}}=\frac{15.790 F 1+4.364 F 2}{15.790+4.364}=0.783 F 1+0.217 F 2
$$

Then we can get the synthesis score of security of China's modern information service industry ranging from 2007 to 2011 by bringing the original data into formula (1) and (2) whose value are then applied to formula (3). The results are shown in table 5 in which the 
synthesis score ranging from 2007 to 2011 is $-3.66,-1.56,-1.09,1.95$ and 4.37 respectively, thus reflecting the increasing improvement of security in China's modern information service industry.

Table 5. Synthesis Score of Major Indicators from 2007 to 2011

\begin{tabular}{cccc}
\hline Year & F1 & F2 & Y \\
\hline 2007 & -4.47 & -0.74 & -3.66 \\
2008 & -2.77 & 2.81 & -1.56 \\
2009 & -0.81 & -2.11 & -1.09 \\
2010 & 2.9 & -1.49 & 1.95 \\
2011 & 5.16 & 1.53 & 4.37 \\
\hline
\end{tabular}

\subsection{Impact Factor Analysis}

Based on factors shown in the above index system, this paper adopts the method of varimax rotation to analyze major factors influencing security of modern information service industry. To be specific, it employs SPSS 19.0 to carry out factor rotation so as to get loading matrix of each component before obtaining the synthesis load by multiplying the loading matrix with contribution rate of corresponding principal components. The synthesis load indicator demonstrates the significance of each factor which is shown in table 6.

Table 6. Load Matrix of Factors after Rotation

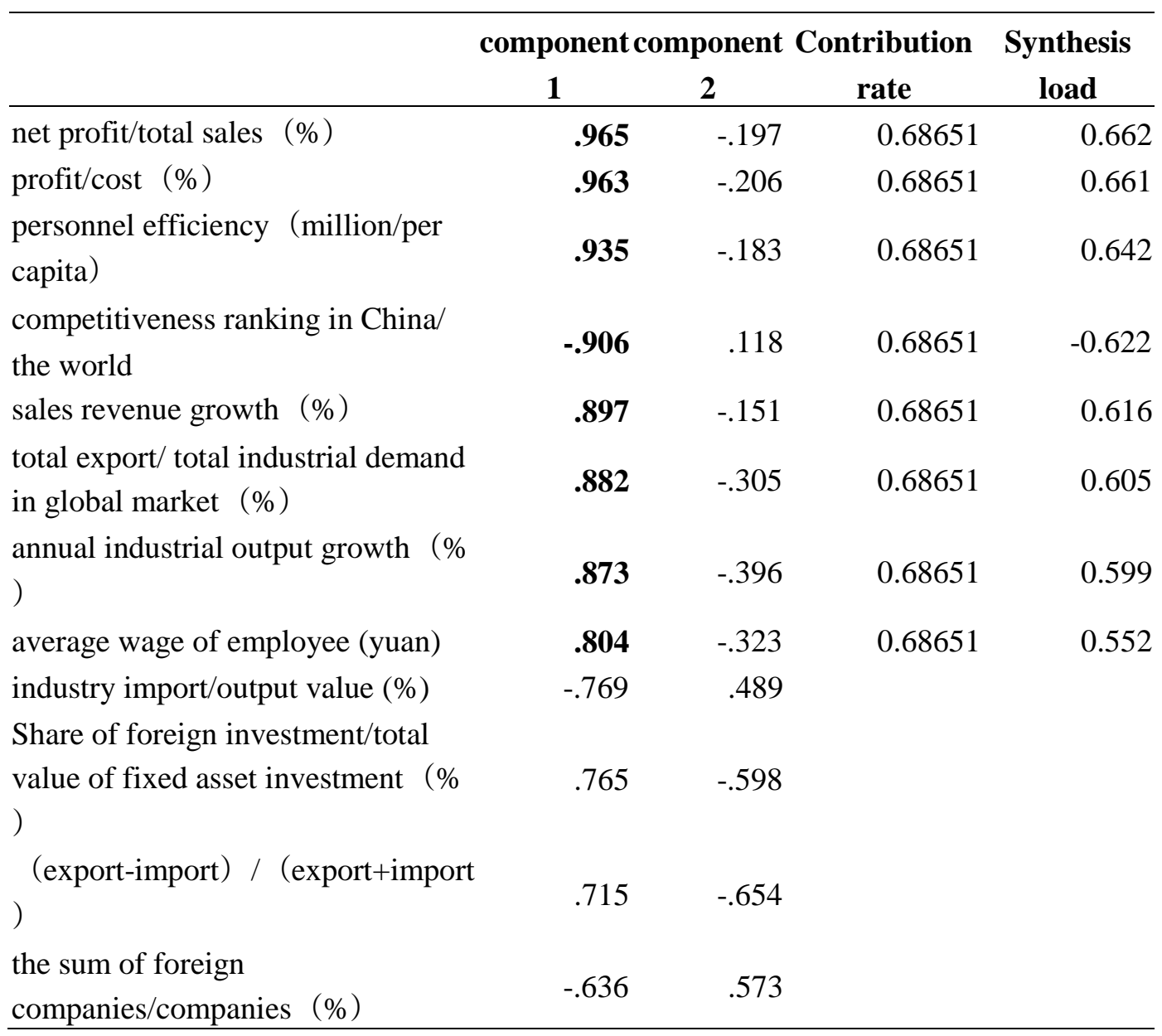




\begin{tabular}{|c|c|c|c|c|}
\hline $\begin{array}{l}\text { the sum of enterprises or national } \\
\text { ones with brand products }(\%)\end{array}$ & .636 & -.573 & & \\
\hline fixed asset investment growth (\% & -.162 & .981 & 0.18974 & 0.186 \\
\hline $\begin{array}{l}\text { foreign-owned/domestic enterprise } \\
\text { sales }(\%)\end{array}$ & -.387 & .664 & 0.18974 & 0.126 \\
\hline $\begin{array}{l}\text { actual foreign investment/total asset } \\
(\%)\end{array}$ & -.519 & .637 & 0.18974 & 0.121 \\
\hline industry export/output value (\%) & .290 & -.208 & & \\
\hline $\begin{array}{l}\text { domestic sales/total industrial } \\
\text { demand in domestic market }(\%)\end{array}$ & -.290 & .208 & & \\
\hline $\begin{array}{l}\text { the proportion of } 10 \text { enterprises } \\
\text { with the largest sale }(\%)\end{array}$ & -.526 & .553 & 0.18974 & 0.105 \\
\hline $\begin{array}{l}\text { Proportion of people with bachelor } \\
\text { degree or above }(\%)\end{array}$ & .106 & .028 & & \\
\hline $\begin{array}{l}\mathrm{R} \& \mathrm{D} \text { expenditure /total value }(\% \\
\text { ) }\end{array}$ & -.218 & .116 & & \\
\hline annual bank loan interest rate $(\%)$ & -.574 & .023 & & \\
\hline $\begin{array}{l}\text { total assets of foreign equity control } \\
\text { corporation/industry (\%) }\end{array}$ & -.318 & -.040 & & \\
\hline
\end{tabular}

It is shown in the table that indicators influencing security of the information service industry are of a decreasing order ranging from net profit/total sales, profit/cost, personnel efficiency, competitiveness ranking in China/ the world, sales revenue growth, total export/ total industrial demand in global market, annual industrial output growth, average wage of employee, fixed asset investment growth, foreign-owned/domestic enterprise sales to actual foreign investment/total asset. Among them, profit/cost, competitiveness ranking in China/ the world, sales revenue growth, annual industrial output growth, average wage of employee as well as fixed asset investment growth belong to industrial indicators of domestic environment, indicating that the domestic industrial environment has exerted the most important influence on security of China's modern information service industry ranging from 2007 to 2011, while other factors like net profit/total sales, personnel efficiency and total export/ total industrial demand in global market fall into the category of international industrial competitiveness which is shown to have an impact on China's modern information service industry only next to the domestic industrial environment. Besides, the rest two factors of foreign-owned/domestic enterprise sales and actual foreign investment/total asset belong to the external dependence of the industry which is believed to have the slightest effect on China's information service security from aspects of influence and the amount of influence factors.

\section{Conclusion and Suggestions}

In accordance with design principles of scientificity, system optimization and practicability, this paper conducted a preliminary evaluation on security of China's modern information service industry ranging from 2007 to 2011 by adopting the method of principal component analysis, while results of the varimax rotation show that reasons effecting security of China's modern information service industry in recent years are the domestic industrial environment, the international industrial competitiveness and the 
industrial external dependence with important indicators influencing security of modern information service industry including return on sales, capital efficiency, labor productivity, macro environment and market demand growth rate.

Therefore, in order to promote security and development of modern information service industry, firstly, we should start from boosting the industrial growth and lay emphasis on investment of capital and labor force so as to ensure the stability of the macroeconomic operation, enhance China's competitiveness in the global market and cultivate a better domestic industrial environment. Secondly, centering on enhancing the market competitiveness, measures should be taken to consolidate the domestic market share and develop foreign market; by means of improving the technical level, we should promote the research and development of products so as to ensure their competitiveness. Furthermore, in addition to strengthening the ability of enterprises to utilize two kinds of resources and markets in the opening up while emphasizing the external dependence of the industry, measures should also be taken to effectively control the industry and protect the industrial security and economic security of our country.

\section{References}

[1] M. Li, Research on Industrial Security Theory (the third edition), Economic Science Press, Beijing (2012)

[2] B. Ji and Y. Liu, On Our Industrial Security, Economic Theory and Business Management. 9, 5-11 (2006)

[3] Y. Jing, Research on Evaluation Index System of Industrial Safety, Economist. 2, 70-76 (2006)

[4] Y. Duan, Evaluation Indexes and Empirical Measurement of the Security of Domestic Equipment Manufacturing Industry, Science and Technology Management Research. 12, 47-52 (2012)

[5] Q. Liu and X. Li, Research on Industrial Security Early-Warning of Industries Invested in China by Transnational Corporations Based on CT and OLS, Operation Research and Management Science. 6, 231-240 (2012)

[6] X. Jia and P. Li, A Preliminary Assessment of the Safety of China's Soybean Industry, Journal of South China Agricultural University: Social Science Edition. 3, 25-32 (2012)

[7] J. Zhu and D. Wei, Re-building of Evaluation Indicator System for Chinese Industry Security and Empirical Research. 7, 146-153 (2013)

[8] H. Schnabl, The ECA-method for identifying sensitive reactions within an IO context, Economic System Research.16, 495-504 (2003) 
International Journal of Security and Its Applications

Vol. 10, No. 7 (2016) 